\title{
The construction of online shopping experience: a repertory grid approach
}

\section{Abstract}

This paper advances the theoretical understanding of online customer experience in the context of e-shopping. Due to the multidisciplinary nature of experience, the relevant prior theories and definitions vary. This paper explores what an online shopping experience is as constructed by consumers, using their own words. Adopting Kelly's (1955) personal construct theory (PCT), twenty-three repertory grid interviews were conducted and analysed using multi-coder qualitative content analysis (with an inter-reliability score of $76 \%$ ). The findings highlight the fluid nature of experience and its construction (emotional, perceptual, situational and behavioural). The variations in meaning explored in otherwise mutually agreed abstractions of what an experience is suggest a need for a strong emphasis on the individualistic dynamic nature of experience, both in theoretical and methodological terms. Accordingly, the paper contributes to theory by adopting a holistic approach that allows a definition of experience from the user's perspective, thus challenging current perspectives on the online shopping experience, and particularly on the emotion, risk perception and situational variables. Key managerial implications for online businesses are provided by highlighting the importance of finding better ways of managing the individualistic experience by focusing on dynamic customer journeys.

Keywords experience; online shopping; repertory grid; emotion; digital environment 


\section{Introduction}

With the rapidly evolving nature of technology, various experiences have shifted either partially or completely to the digital world, including the shopping experience (Bilgihan, 2016; Pantano and Priporas, 2016) and the service delivery experience (McLean and Wilson, 2016). Indeed, as the Internet has become a major channel of product and service delivery, and as a new generation of 'digital natives' (Akçayır, Dündar \& Akçayır, 2016; Prensky, 2001) has become a key target for major retailers, the online shopping experience has taken on vital importance. In fact, experience is considered "the key battleground for today's global competition" (Weinman, 2015). Despite its fundamental importance, online shopping experience research is still limited and fragmented (Anteblian, Filser, and Roederer, 2013; Bilgihan, Kandampully \& Zhang, 2016; Klaus, 2013; Mclean \& Wilson, 2016; Rose, Clark, Samouel \& Hair, 2012; among others). Most notably, the existing literature focuses on the antecedents and consequences of the online shopping experience (e.g. Bilgihan et al., 2016; Rose et al., 2012). Although understanding the antecedents and consequences of experience are important, such an approach rarely explores the essence of the experience itself in any great depth (Petermans, Janssens \& Van Cleempoel, 2013).

Other popular approaches include the use of flow theory in which optimal experiences are studied and their nature is explored (Hoffman \& Novak, 1996; Chen, Wigand \& Nilan, 1999; Liu, Chu, Huang \& Chen, 2016; Skadberg and Kimmel; 2004). However, this type of research focuses only on optimal experiences and the experience of flow, rather than examining any other types of experience. In doing so, flow research falls short of addressing the many popular experiences of online shopping in which a state of flow is not reached. In addition to the aforementioned 
research, explorations of user experience design are a popular research stream in which web atmospherics and the online shopping environment are carefully designed to deliver certain experiences (Petermans et al., 2013; Pine \& Gilmore, 1998; Schmitt, 1999; Weinman, 2015).

A lack of holistic approaches to the essence of experience is evident in the existing research, as the focus usually seems to be on parts of the experience, and/or its antecedents or consequences. This becomes problematic when approaches to improving the online shopping experience are made without first meaningfully and holistically understanding what constitutes an experience (Kamaladevi, 2010). As has been observed: "Holistically inspired research on customer experiences in retail environments seems to be truly scarce" (Petermans et al., 2013, p.1). Furthermore, due to the multidisciplinary nature of experience it is difficult to reach a unified definition of what an experience is (Carù \& Cova, 2003); therefore, there is a need to better establish an agreed theoretical understanding of the online shopping experience as a holistic and individualistic phenomenon (Carù \& Cova, 2003).

Drawing on these issues, this research argues that a concept as important as experience, clearly discussed as a key strategic goal for businesses (Klaus, 2013), and as a key battleground for global competition (Kamaladevi, 2010; Weinman, 2015) should be explored in depth in order to establish the essence of what an experience is and to understand the implications of that essence in business and design contexts. This research aims to explore the essence of the online shopping experience as constructed by online users, using their own words and constructions. Specifically, the objectives of this paper are to:

1. Explore the concept of experience in the context of online shopping from a user perspective 
2. Move beyond existing models and theories to unveil the essence of experience as lived and constructed by the consumers

3. Adopt a holistic approach in which the experience is discussed as a whole rather than as a fragmentation of antecedents and consequences.

The present paper therefore begins by critically reviewing the literature associated with customer experience and online shopping experience.

\subsection{Experience and Environment Design}

The rise of experience as a concept is manifested in a focus on the experiential attributes of shopping for products and services alike. The argument suggests that hedonism and emotions are key factors in shopping, and that therefore, focusing on these experiential attributes is important (Hirschman \& Holbrook, 1982). However, this view was quickly critiqued as it seems to suggest that experience is simply a shift from rational thinking; thus, researchers such as Schmitt (1999) discuss the possibility of designing experiences that can be either emotional, rational, or behavioural, etc., by manipulating the design of the environmental cues in which the experience takes place. Existing literature that employs this approach to understanding experience uses key psychological theories of emotion such as the Stimuli-Organism-Response (SOR) model (Russell \& Mehrabian, 1977), the wheel of emotions (Plutchik, 1980), and Richins' (1977) consumption emotion set (for example, Chaudhuri, 1997; Holbrook \& Gardner, 1993; Kim \& Lennon, 2010; Koo \& Ju, 2010).

In addition, such research usually focuses heavily on the design of the environment in which the experience takes place. Pine and Gilmore (1998) refer to the experience in this sense as a theatrical one, in which four realms of experiences can be designed: these are esthetic, escapist, entertainment and educational. 
Arguably therefore, in the context of online shopping experience, web atmospherics act as stimuli that trigger certain emotional states in the shopper, leading either to positive or negative experiences. In this focus on the online shopping environment as a key influencer in the online shopping experience, various adaptations to existing terminology appear. For example, the traditional shopping experience literature uses terms such as "environmental cues" and "atmospherics" (Kotler, 1973), “servicescapes" (e.g., Bitner, 1990) and "store environments" (e.g., Grewal, Levy \& Kumar, 2009; Baker, Parasuraman, Grewal, and Voss 2002). In order to study the online shopping experience, these terms had to be adapted to the online context as “web atmospherics" and "environmental cues” (e.g., Kawaf \& Tagg, 2012; Kim \& Lennon, 2010), “online servicescapes” or “e-servicescapes” (e.g., Lee \& Jeong, 2012), to refer to the virtual environment.

An example of this approach was given by Eroglu, Machleit and Davis' (2001) adaptation of the predominant SOR model (Russell \& Mehrabian, 1977) in which a new taxonomy of online atmospheric cues was suggested to include low and high task relevance cues. A clear focus was placed by these authors on online environmental cues, ranging from focusing on exploring what these cues "really" are to examining website quality (Demangeot and Broderick, 2007; Dailey, 2004), website brand (Chang \& Chen, 2008), and web design (graphic and colors) and layout (links and menus) (Koo \& Ju, 2010) (see Figure 1, below).

Although this stream of research is invaluable in understanding the digital environment and its atmospherics, it places little or no emphasis on the role of the consumer in their own experiences. Because the central focus of this type of research is to closely examine the environment and customer responses to it, the customer is ultimately viewed merely as an organism responding to external stimuli; thus, such 
research rarely engages with the nature of experience itself. Therefore, experience appears to be understood in terms of the effect of web atmospherics on the individual. This view is not only problematic due to the lack of focus on the individual, but also because these design-driven approaches apparently assume that a stimulus could possibly work in isolation from all other stimuli, and apply to one or another type of experience. This problem is highlighted by Dennis, Brakus, Gupta, and Alamanos's argument that: "little information is known about the type of specific experiences that are evoked by atmospheric in-store elements and how these experiences affect consumers' affective and cognitive reactions as well as their approach behaviour" (2014, p.2250). As a result, a lack of a holistic understanding of the nature of experience is often evident (Petermans et al., 2013).

\footnotetext{
Online Shopping Environment

Web atmospherics

SOR adaptation (low and high task relevance cues)

Web Design

Web Quality

\section{Online Shopping Experience}

Emotion

Cognition

Figure 1 The environment and the experience

\subsection{Antecedents and Consequences}

In addition to the environment design approach, a notable stream of research addresses experience by studying its antecedents and consequences. For instance, Bilgihan's (2016) recent conceptualisation of the online experience resulted in the identification of eight key antecedents to the web experience: ease of location of the website/app, ease of use, perceived usefulness, hedonic and utilitarian features, perceived enjoyment, personalization, social interactions, and multi-device
} 
compatibility. Of these antecedents, ease of use and perceived usefulness are the popular key constructs of the widely-used Technology Acceptance Model (TAM) (Ha \& Stoel, 2009; King \& He, 2006; Koufaris, 2003; Lee, Kozar, \& Larsen, 2003). Although TAM is not specifically adapted to studying the online experience, it is a helpful framework for measuring consumers' responses to the online environment. In addition to Bilgihan's (2016) conceptualization, Rose et al. (2011) identify the antecedents of online shopping experience as information processing, perceived easeof-use, perceived usefulness, perceived benefits, perceived control, skill, trust propensity, perceived risk, and enjoyment. Like Bilgihan's (2016) key antecedents, Rose et al. (2011) include the TAM constructs as well as hedonic and utilitarian features (enjoyment and information processing). However, unlike Bilgihan (2016), they also discuss trust and risk as antecedents to the experience, in addition to a clear apparent role for the individual indicated by the inclusion of skills and control.

Other antecedents to the online shopping experience identified as macro factors are: promotion, price, merchandise, supply chain and location (Grewal, Levy \& Kumar, 2009), as well as brand, advertising, packaging \& labeling, service mix, and atmosphere (Kamaladevi, 2010). Consequently, this type of research has attempted to study the macro influencers on the experience as opposed to the micro ones. The key antecedents are summarized in Figure 2 below.

Across this stream of research, the outcomes or consequences of experience are established as positive outcomes that include increased revenues and brand engagement, positive word of mouth, satisfaction, and repeat purchase (Bilgihan, 2016, Rose et al. 2011) (see Figure 2, below). 


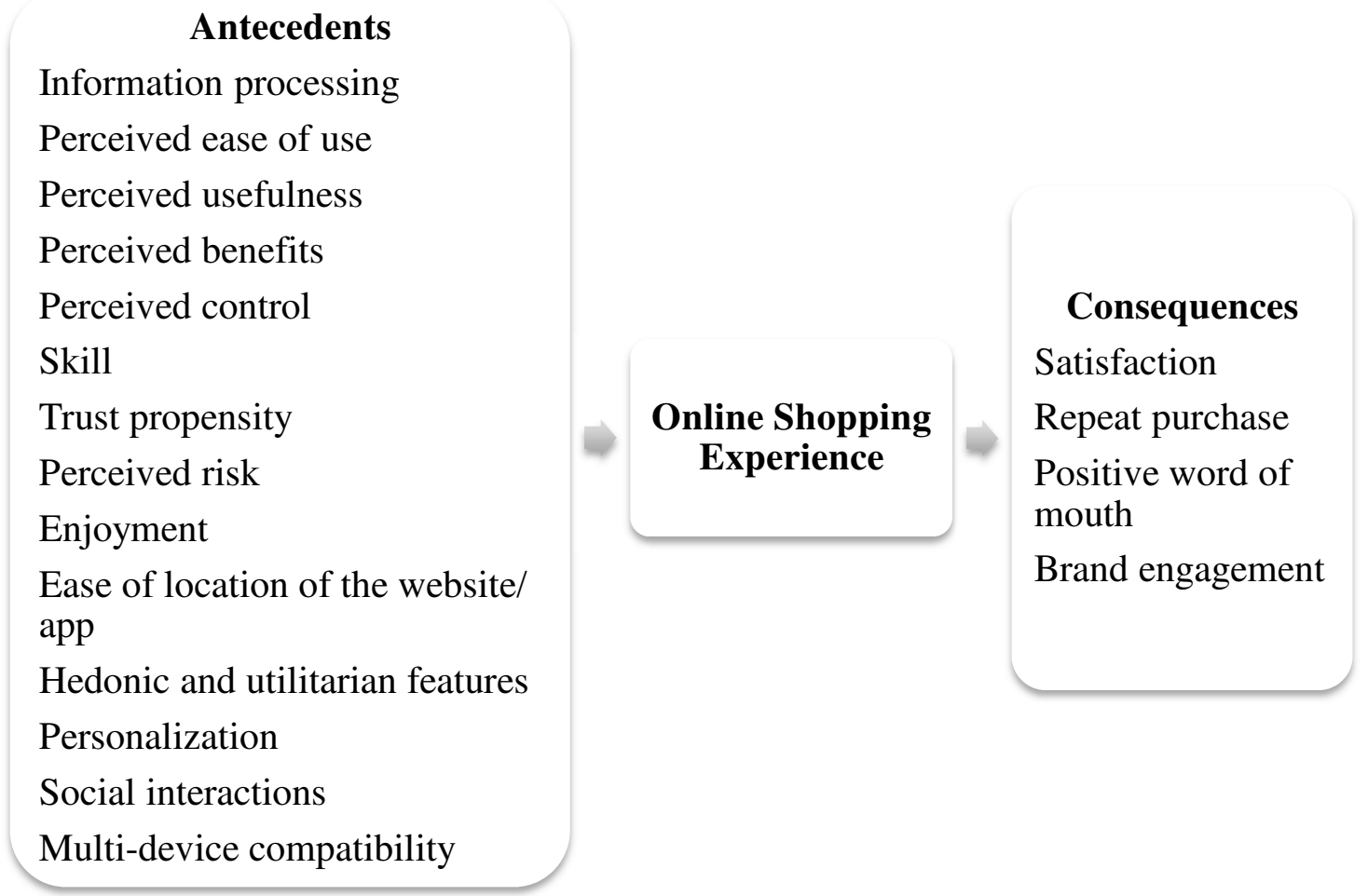

Figure 2 Antecedents and Consequences

Although, as has been discussed above, this stream of research has identified a comprehensive list of antecedents to the experience, its approach rarely explores the essence of the experience itself in any depth (Kamaladevi, 2010; Petermans et al., 2013). It is also problematic in its view of the experience as an ultimately positive phenomenon resulting in positive outcomes such as satisfaction, repeat purchases, brand engagement, and so on. While this might be the case in a positive online shopping experience, there is no reason why the concept of 'experience' should be limited purely to positive instances. Instead, it should be further explored to address other types of experiences, including less positive and even negative ones.

\subsection{Experience of Flow}

The third stream of research uses flow theory to study the nature of specific online experiences, namely optimal experience or the experience of a state of flow (Bridges \& Florsheim, 2008; Lee \& Jeong, 2012; Novak, Hoffman \& Yung, 2000; Pace, 2004; 
Su, Chiang, Lee \& Chang, 2016). Flow is defined as a: "state of consciousness that is sometimes experienced by individuals who are deeply involved in an enjoyable activity" (Pace, 2004, p.327), and the term "flow" was initially coined in this research context by Csikszentmihalyi (1990), before being brought to online experience research by Hoffman and Novak (1996). During online navigation, the cognitive state of flow is: "determined by: 1) high levels of skill and control; 2) high levels of challenge and arousal; 3) focused attention; and is 4) enhanced by interactivity and telepresence" (Novak et al., 2000, p.4). A perception of the balance between the user's skills and the challenges involved in the interaction is essential to experiencing flow (Pace, 2004) and its importance, as it: "underlies... a compelling online experience" (Novak et al., 2000, p.2). Novak et al. (2000) empirically tested the concept to provide supporting evidence, then Pace (2004) used it in further theory building. Furthermore, flow theory is extensively embedded in the study and design of online customer experience and in human-computer interactions. Examples of this approach have been evident in studies such as Chen, Wigand and Nilan's (1999) work on optimal experiences of web activities and Webster, Trevino and Ryan's (1993) dimensionality of flow in human-computer interactions, in addition to more recent work on flow experience (Ho \& Kuo, 2010; Liu et al., 2016; Skadberg \& Kimmel, 2004; Su et al., 2016, among others).

This approach enriches experience research because it attempts to establish understanding of what an experience actually is, examining and highlighting the state of the individual within the experience. However, with its goal-oriented postulation, flow theory only explains certain types of experiences: those that meet the conditions required to achieve a state of flow. This leaves flow theory unable to explain possible types of experiences that do not achieve a state of flow. A state of flow does not 
necessarily persist throughout the shopping experience, and sometimes may not happen at all. Thus, whilst flow theory is appropriate for studying optimal experiences, it is not a suitable approach to employ in a holistic inquiry into understanding the nature of experiences with any of its phases, regardless of whether they are optimal or not.

This literature review has discussed the existing research on the online shopping experience. As illustrated in Figures 1 and 2, the two main streams of literature concerned with experience focus on understanding either how the digital environment influences this experience, or what the antecedents and consequences of online shopping experience are. While the existing research is invaluable in attempting to explain what influences the experience (the environment or other explained antecedents), little knowledge has been established about the nature of the experience itself. Limited prior research has been found which addresses this issue effectively, especially empirically. Indeed, there is an apparent lack of a unified approach to examining the essence of experience in the existing research (Petermans et al., 2013). It is argued throughout this literature review that the online shopping experience is a fundamentally important concept that should be explored in depth (Kamaladevi, 2010). To date, existing reviews of the literature suggest that no single definition of what an experience is has been agreed (Carù \& Cova, 2003); therefore, there is a need to better establish a unified theoretical understanding of the online shopping experience as a holistic and individualistic phenomenon (Carù \& Cova, 2003). This study therefore moves beyond the existing frameworks and models to explore experience from a consumer perspective, an approach which empowers consumers in relation to their own experiences. Therefore, the paper addresses the question of how consumers construct their own online shopping experiences; in other words, what 
makes an experience for a customer, and how is the subjective nature of experience (Gentile et al., 2007; Meyer et al., 2007; Rose et al., 2011) evident in data? How can we arrive at a comprehensive understanding of the term when it is, arguably, individualistic and subjective?

Accordingly, this research aims to explore the essence of the online shopping experience as constructed by online users and using their own words and constructions. It moves beyond the existing literature to answer calls for a holistic approach to studying the essence of the online shopping experience, and explores what constitutes an experience rather than what may influence it.

\section{Methods}

\subsection{Background}

In order to meet the research objectives, this paper adopts Kelly's (1955) personal construct theory (PCT) and employs the repertory grid technique as its method of data collection. PCT is a humanistic approach of inquiry that accounts for the role of the person as a whole, and sees an individual as one who is capable of learning from his or her experiences and constructions of the world. PCT is described as "man's personal inquiry—a psychology of the human quest" (Bannister, 1970), viewing "man as a scientist" and as an expert in his/her own experiences, and therefore as the best source to guide us into understanding his/her experiences in a holistic manner (Bannister \& Fransella, 1986).

In accordance with PCT, the repertory grid technique is a method designed to help the individual to unveil his or her constructs. Unlike other types of measurement, the grid does not impose any content dimensions on the participants. Instead, the participants 
are invited to use their own words to construct their experiences and their understanding of these experiences (Bannister \& Mair, 1968).

This method has been adopted and adapted from existing research, where it has been used both qualitatively and quantitatively as an exploratory tool, a tool for evaluating choices or decisions, or a method of inquiry into human perception, emotion and cognition (for example, see Lemke, Clark \& Wilson, 2011; Marsden \& Littler, 2000; Richardson, et al. 2002; Tagg \& Wilson, 2011; Walker, et al., 2003, among others).

\subsection{Data Collection Method}

Every repertory grid consists of a topic, elements, constructs, and ratings. As Jankowicz explains: "people have constructs about anything and everything. A grid is always conducted about a particular topic, with the intention of eliciting just those constructs which the person uses in making sense of that particular realm of discourse - that particular slice of their experience" (2005, p.12). The grids collected in this research depict online shopping experiences.

In this research, the participants were asked to choose the elements of the grids with respect to different web atmospherics and characteristics. Once the elements were chosen, construct elicitation began. Any means of element comparison can result in construct elicitations (e.g., dyads, triads, etc.). However, Kelly (1955) suggests the use of triads as the most appropriate method. This study follows Easterby-Smith et al.'s Minimum Context Card Form in which "the cards are normally drawn randomly from the pack and triads are presented until time runs out or the person 'dries up'", (1996, p.9).

In this research, three elements cards were picked by each participant, who was asked to say in which way two of these cards (elements/ websites) were similar and different 
from the third, in terms of their own experience. The participant's answer for the similar (common factor) between two of the cards was recorded on the very left hand side of the grid as the "emergent" pole of the construct. In contrast, the participant's answer regarding how the two cards differed from the third was recorded on the righthand side of the same row to represent the "implicit" pole of the same construct. After eliciting the construct, each participant rated all the elements of the grid on a 5-point Likert scale of the construct itself.

Another construct elicitation process called "laddering/pyramiding" follows, wherein "the person is able to indicate the hierarchical integration of their personal construct system” (Bannister et al., 1968, p.50). In this process, in-depth questioning about the initial construct ("why" and "in what way") results in further constructs (Jankowicz, 2005). Appendix 1 shows an example of a grid.

\subsection{Research Sample}

An important stage in the research process is research sampling, which is: "the stage in which the researcher determines who is to be sampled, how large a sample is needed, and how sampling units will be selected" (Zikmund \& Babin, 2007, p.27). Sampling techniques are classified into two distinctive types; probability and nonprobability samples (Saunders, Lewis, \& Thornhill, 2009). While the former relies on probability theory, it is the latter that is widely used in qualitative research mostly in the form of purposive or judgmental sampling (Creswell, 2009; Goulding, 1999). In purposive sampling, members are chosen based on the judgement of the researcher and in relation to the research problem. In line with the present research's focus on the construction of the online shopping experience, the selection criterion is that a person must have recurrent experiences of online shopping including purchase and post purchase experiences in order to participate. 
Due to this research's focus on the fashion industry, the authors sought participants who not only had recurrent online shopping experiences, but specifically fashion related ones. Arguably, a person who browses online for products but prefers to buy in store is not living the same experience as purely online buyers in that he or she is not taking purchase related risks such as monetary risks (see Appendix 2 for participants' profiles). This approach is in line with Goulding's rationale that "the participants are selected because they have 'lived' the experience under study, and therefore sampling is planned and purposive" (1999, p.868).

The process of data collection began by conducting a structured repertory grid-style interview with every participant. In this type of research, interviews are carried out until theoretical saturation is reached, which means the point at which it is decided that no additional data would result in any new insights (Creswell, 2009; Goulding, 1999). Accordingly, 27 individual repertory grid interviews were conducted, of which 23 were recorded and analysed following pilot design modifications of the first 4 grids.

\subsection{Analysis}

"Grids are like people. They come in many shapes and sizes, they ask questions and give answers, they can be studied as a group or individually, on one occasion or successively over time" (Fransella, Bannister, \& Bell, 2004, p.xi). In order to identify the constructs of experience (i.e. how online shoppers construct their experience), analyses of individual and collective grids were performed in keeping with PCT's precepts. Initially, the individual evaluation of grids was done via eyeball and process analyses to establish a general feel for the data and a basic understanding of the findings (Jankowicz, 2005). Then, Nvivo word frequency analysis was undertaken to establish a generic view of recurring constructs. Finally, an advanced multi-coding 
qualitative content analysis of all constructs was performed. Because the use of multicoders and ensuring a high reliability between results helps in establishing rigour in the analysis, a further four researchers participated in qualitatively coding the constructs.

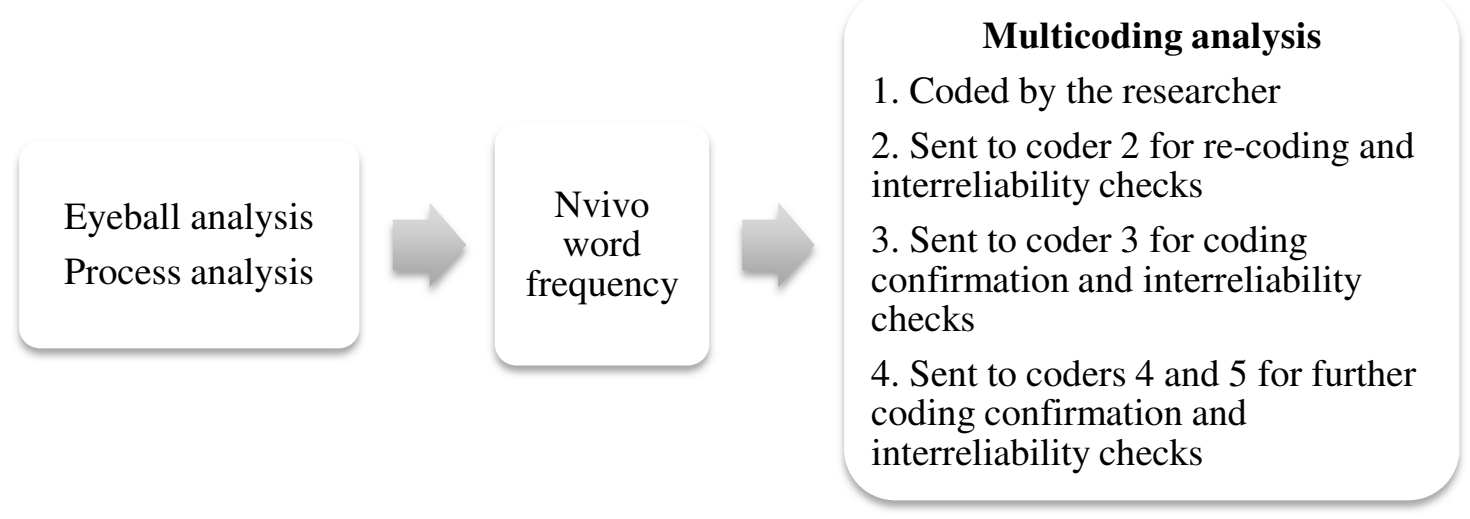

The initial process of analysis established the codes of constructs according to the existing research, and used quotes from the interviews to further explain these constructs. A second researcher independently repeated the initial coding step, the results were compared and discussed, and initial categories of constructs were established. After deleting duplicates and closely similar constructs, a reduced version in the form of a set of 100 constructs was produced, which was then sent along with the agreed categories to coder 3 who re-coded all the constructs into the predefined categories, and an inter-reliability index was calculated by comparing the coding results. This process was repeated twice by two additional coders, reaching a final inter-reliability index of $76 \%$. This is an acceptable score when compared to that achieved by a similar study by Lemke et al. (2011).

\section{Results}


The results of the multi-coding process of all constructs were used to classify the construction of online shopping experiences. Table 1 presents this classification as a taxonomy of what makes an experience using consumers' own constructs.

Table 1 Constructs classification (Explicit-Implicit)

\begin{tabular}{|c|c|}
\hline $\begin{array}{l}\text { Elements: } \\
\text { Importance } \\
\text { and Influence }\end{array}$ & $\begin{array}{l}\text { advanced elements—basics; assessment—usage; base my decision on—initial } \\
\text { steps; better feel of the product-closer to real life—I don't care; bonus— } \\
\text { necessity; clear—unnecessary ; closer to real-life experience—ignore it; closer } \\
\text { to real-life experience—-biased; closer to real-life experience—a good; service- } \\
\text { time saver; closer to real-life experience—can't see or feel the product; closer to } \\
\text { real-life experience—not impressive; closer to real-life experience (realistic) —- } \\
\text { far away-discard; encourage me to buy—irritate me; encourage me to buy—put } \\
\text { me off; essential—reinforcing; essential-vital—useless; give you more details- } \\
\text { make products closer to real life; glamorous—expected; help me buy—put me } \\
\text { off; help me decide later—initial liking; help you choose product—help you } \\
\text { choose company; important—extra; important—don't bother; important—- } \\
\text { useless; influence my purchase decision—it doesn't matter; influence my } \\
\text { purchase decision—I won't be affected; influence my purchase decision—give } \\
\text { information; initial liking—actual purchase decision; initial liking—reassures } \\
\text { me -make me calm; it is a good alternative to store service—the minimum } \\
\text { basics; it would tell you more about the product—it would make you confused; } \\
\text { make me imagine the product—make me closer to obtain it; more attractive—a } \\
\text { nice extra; motivate me to buy—difficult to judge on; motivate me to buy— } \\
\text { make me informed; precise-focused—imprecise-lost; they let you see the } \\
\text { clothes in action—finding a store in the first place }\end{array}$ \\
\hline Emotions & $\begin{array}{l}\text { comfortable—disappointed; comfortable—doubtful-unsettled-confused; } \\
\text { comfortable—-stressful; concerned—happy; confident—doubtful; confident—- } \\
\text { inspired; confident—unsure; confused—enjoyment; enjoyable-having fun—- } \\
\text { irritated; enjoyment-satisfaction—dislike it; excited—guilt; facilitate my } \\
\text { choice—anxious about my choice; feel at ease—disappointed; feel valued—- }\end{array}$ \\
\hline
\end{tabular}




\begin{tabular}{|c|c|}
\hline & $\begin{array}{l}\text { feeling like 'a till number'; glad-happy—disappointed; happier overall— } \\
\text { focused; happy—-frustration; happy—confusion; happy you get it } \\
\text { (achievement)—unhappy and thinking about it (consciousness); happy- } \\
\text { motivated—unsure; inspired—-bored; inspires me—reassures me - but might put } \\
\text { me off; interested—-bored; interested—ignore; interested-happy—unsure-try to } \\
\text { imagine; involved—don't bother; motivate me—disappointed-distracted; } \\
\text { motivated—frustrated; motivated—confused; neutral (tend to ignore) — } \\
\text { dissatisfied-upset; neutral-don't care—happy; not bothered—-motivated; pay no } \\
\text { attention—assurance; pride—guilt; reassured—distracted; reassured—- } \\
\text { dissatisfied; reassuring—irritating; reassuring—annoying; satisfaction—- } \\
\text { contempt; satisfied—disappointed; satisfied—nervous-angry; satisfied—- } \\
\text { annoyed; unhappy—confident; a benefit—drawback }\end{array}$ \\
\hline Risk and Trust & $\begin{array}{l}\text { biased—trustworthy; certain—uneasy; high-risk purchase—low-risk purchase; } \\
\text { more confident—not guaranteed that you get what you're looking for; more } \\
\text { confident about my choice—-trust the company; more confident that the product } \\
\text { is right for me—easier-simpler; trust—doubtful; trust—not reliable; trust—- } \\
\text { distrust; trusting the website—annoyed-disappointed; at ease—scared }\end{array}$ \\
\hline Behaviour & $\begin{array}{l}\text { buy more—put you off; go back to the website—find an alternative; more likely } \\
\text { to buy—leave the website; more likely to buy—-might look for alternatives; } \\
\text { search for cheaper or buy—give up; willing to buy more—might choose another } \\
\text { website }\end{array}$ \\
\hline Situation & necessity—luxury; I need the product—I am just looking for inspiration \\
\hline
\end{tabular}

Note: constructs separated by ';')

As Table 1 shows, the construction of experience consists of emotional and behavioural constructs, in addition to constructs relating to trust and risk perceptions, and the perception of a shopping environment's "web atmospherics." The following subsections elaborate on each of these constructs.

\subsection{Perception of the environment}


At the most basic level, experience construction consists of a perceptual evaluation of web atmospherics and online environmental cues. In this group of constructs, the participants commonly agreed that they perceive most web elements as "essential" and that in online fashion shopping, advanced atmospherics such as catwalk videos are no longer a luxury, thus implying a level of expectation which must be met by service providers (including online fashion retailers).

Furthermore, a remarkable emerging theme in this group of constructs is the suggestion that the ultimate role of web atmospherics is to bring the online fashion shopping experience closer to that of "real life". As Table 1 shows, various constructs in the elements "importance and influence" group refer to "closeness to real life experiences" as a core construction point. This is also evident in the participants' comments on the issue. For instance, one participant suggested that the construct (closer to real life - you can't see or feel the product) differentiates between web characteristics that facilitate an experience that is as close as possible to store shopping where items are seen, touched, and tried on, and those which do not facilitate this experience. Talking about product images and catwalk videos, this participant commented that:

"You can see how it looks like in real life and you can see if someone's modelling it. [Talk about written product information] yeah it doesn't... it could tell you what it looks like but you cannot see it. Like that's an advantage of going to the shops just so you can see it and feel it" (Interview 05)

"Closeness to real life" constructs are used (a) to differentiate among elements that facilitate an online experience similar to a brick-and-mortar shopping experience and elements that fall short of doing so; (b) as a means of expressing perceptions of an element's importance; and/or (c) as a risk reduction scale linked to confidence and 
trust. Accordingly, the first group of constructs, which relate to elements' importance and influence, represent the initial, most basic level of construction of the online shopping experience.

\subsection{Emotion}

"Happiness," "disappointment," and "confidence" are among the most frequently repeated words in the constructs' word frequency test. Additionally, words such as "confusion" and "reassurance," followed by "satisfaction," "comfort" and "frustration" were mentioned in several grids.

One of the most recurrent emotional constructs was one that included 'happy' or 'happiness' either as an emergent or implicit poles (e.g. concerned—happy; gladhappy—disappointed; happier overall—focused; happy—frustration; happy— confusion; happy you get it (achievement)—unhappy and thinking about it (consciousness); happy-motivated-unsure; neutral-don't care-happy) By applying PCT's concept of (emergent-implicit) constructs, it is possible to explore a person's construing system and to understand what they mean by a concept by revealing what its contrast is to them. Therefore, it is important to differentiate what is meant by "happy" by examining its contrasts, such as "frustrated," "concerned," "focused" or "confused". By analysing these different contrasts, it is then possible to highlight the individual difference in the meaning of 'happiness' and how it reflects on one's experiences. For example, one participant identified "happy-disappointed" as a construct, explaining that:

“I am quite glad because I didn't have to errm 'move' [meaning she did not have to go to the shop and was able to do it online] and I could find what I wanted ... and I mean it makes me think like 'oh so they do actually care about the customer" (Interview 9) 
On the other hand, another participant explained his construct (happy-confusion) as follows:

"If I can find all the information I need about the product I need, I am happy, I am buying it. Reassured!' (Interview 6)

Another frequently repeated construct revolves around the notion of disappointment.

Indeed, in most instances the contrast to disappointment that comes to mind is satisfaction. In this case, disappointment refers to a state of unmet expectations. However, disappointment also appears with contrasts such as "comfortable" and "trust" thus implying a different meaning. For instance, one participant revealed “comfortable-disappointed" as a construct, saying:

"I can see texture and I can see movement and that definitely makes me more comfortable buying. Because sometimes when you see things just as a picture, then you get it home and it's not what you expected to be and then after a wee while that builds up and you think hmm I am not buying from that site anymore because then I'm just disappointed every time I get something" (Interview 20)

The previous examples of the word disappointment in constructs differ substantially from instances where disappointment is paired with words such as trust, or motivated. Another participant suggests in reference to "trust-disappointment" that:

"It's like it reduces the chance of being a... the website being like a fake, so you're not gonna get scams, because the website is well established online" (Interview 13)

A variety of other examples were found throughout the dataset (see Table 1). While there is insufficient space for all these constructs to be unpacked here, the examples do reflect these variations in the usage of otherwise widely known and commonly 
used emotional words. Thus, the results highlight the fluid nature of emotions as a new insight into experience construction; meaning that the nature of experience varies from one individual into another due to this fluidity.

The construction of the online fashion shopping experience, thus far, involves constructs relating to perceptions of the environment, and emotional constructs. The following section discusses a third category of constructs: those which relate to risk and trust.

\subsection{Risk and Trust}

It is perhaps surprising that in constructing their experiences, few of the present study's participants explicitly mentioned risk as a part of their constructs. Despite appearing in some grids, high risk rarely figured as a part of the experience. Table 2 shows the instances where risk was mentioned as a part of a construct, and how such constructs are rated.

Table 2 Risk-construct ratings

\begin{tabular}{|c|c|c|c|c|c|c|c|c|c|c|c|c|c|}
\hline $\begin{array}{c}\text { Risk-free Purchase } \\
\text { Decision }\end{array}$ & 1 & 3 & 2 & 2 & 3 & 3 & $\mathbf{5}$ & 2 & 3 & $\mathbf{4}$ & $\begin{array}{c}\text { High risk/Unable to } \\
\text { purchase }\end{array}$ \\
\hline Low risk & 3 & 2 & 3 & 1 & 3 & 3 & 3 & 1 & 2 & 1 & High risk \\
\hline High-risk purchase & 3 & 3 & 3 & 5 & 3 & 3 & 5 & 3 & 3 & 3 & Low-risk purchase \\
\hline
\end{tabular}

Table 2 highlights that ratings toward the "high risk" pole of the constructs are minimal, thus suggesting that participants' perceptions of high risk were marginal. Perhaps this relaxed outlook on risk is because of the participants' high familiarity with online fashion shopping. However, it seems that being able to return unwanted items easily, and often free of charge, has dramatically reduced customers' 
perceptions of risk. In fact, for some participants, the notion of risk only refers to not being able to make purchases or access the fashion website (e.g., in the first line of Table 2, ratings of 4 and 5 suggest that high risk is attributed to factors such as mobile access and filters). The highest risk perceived by that participant related to being unable to access a website or find a needed item via the filtering options, rather than because of any sense of financial or product risk.

This lack of orientation to risk among the participants may seem surprising, as online shopping literature has always emphasized the importance of this issue especially in the context of online fashion shopping. However, despite the prior research focusing on risk reduction in online fashion shopping, it is arguably not a relevant construct for online fashion shoppers themselves in terms of their individual experiences. Indeed, risk reduction is significantly different in non-online shoppers, in which case addressing risk issues remains valid in order to attract non-online shoppers to online shopping, but this lies beyond the scope of this paper.

In contrast to risk, trust was central in this group of constructs. A variety of different constructs which include the word trust are listed in Table 1; most notable are trust vs. unreliable/biased, trust vs. frustration, and trust vs. disappointment. As is the case with emotional constructs, trust varies in meaning in these instances when PCT logic is applied.

An example of this shift in meaning is evident in the trust vs. unreliable/bias construct, which a participant uses to suggest that bias and unreliability (e.g. in relation to customer reviews) are elements of fashion websites. However, instead of processing such unreliable sources, the participant selectively chooses to focus on elements he or she can trust, such as web layout, high quality webpages, and high quality products, by using zooming-in features and 3D images. 
On the other hand, constructs such as trust-frustration and trust-disappointment convey a different perspective. For example, one participant explained that she trusts a website when it meets or exceeds her expectations, but if the site fails to deliver her items, she will not trust them and will feel disappointed. Her concept of trust is not related to the risk of anything being fake, but rather, it relates to her belief that a website will meet her expectations and strive to satisfy her needs.

\subsection{Behavioural Constructs}

This category of constructs relates to the types of behaviours that the study participants mentioned. These behaviours range from exploring, buying, and revisiting to being put off, looking for alternatives, leaving the website, and giving up. It is notable that in constructing the experience of online shopping, anticipating a positive behaviour is much more common than anticipating a negative one.

\subsection{Situational Constructs}

The final category of constructs refers to the contextual situation in which the experience takes place. In the case of fashion shopping, it forms a significant part of the construction because of its impact on experience. The situation can be defined as the nature of the shopping task, the purpose of the shopping, or any other defining aspect that may change the shopping experience. An example is "necessity-luxury," a construct suggested by a participant who clarified that, to her, the concept of luxury does not refer to the purchase of luxury fashion items but to buying products that are not necessary or desperately needed. Buying clothes that she does not desperately need is a "luxury," and knowing that she can return them if she does not like them is another "luxury," whereas a "necessity" means that she needs the item immediately or for a specific occasion; the scope of error she is ready to make is minimal in this case, thus such situations shape her experience. 
It is apparent that such changes in the individual's situation impact on their whole experience and presumably on their interactions with fashion websites. As shoppers shift from desperately looking for one specific item to randomly exploring a new collection of items, for instance, the nature of their experiences changes dramatically. Therefore, the results highlight the importance of situational variables and include them as core aspects of constructing online fashion shopping experiences, and of the contextual whole that defines them.

\section{Discussion}

The current paper sought to explore the essence of the online shopping experience as constructed by online users, using their own words and constructions. The results of this study reveal five categories of constructs that form the online shopping experience and define its essence. These categories are (1) perception of the environment, (2) emotional constructs, (3) risk and trust constructs, (4) behavioural constructs, and (5) situational constructs. More importantly, the study highlights important insights into many of these categories. For instance, the first group of constructs highlight the important role of web atmospherics as a tool to bring the online shopping experience closer to 'real life'. The role of the shopping environment and web atmospherics is widely studied is existing literature (e.g. Bilgihan, 2016;

Eroglu, et al., 2001; Pine \& Gilmore, 1998; Rose, et al., 2011; Schmitt, 1999). Unlike this stream of research, this finding does not examine the influence of the online shopping environment nor does it regard it as an antecedent to the experience. Instead, the finding here reveals that a customer's perception of the shopping environment constitutes an essential part of their experience in its holistic form. The significance of this resides in the emphasis on the perceptual constructs of the environment rather than the environment itself, thus showing that even though the online environment is 
arguably the same for all customers, it is perceived differently, resulting in one or another type of experience for different individuals.

Furthermore, the results also reveal emotion as a significant part of the online shopping experience. However, emotional constructs as highlighted in the results reflect an important aspect of fluidity that defines the individualistic nature of the shopping experience. The results identify variations in the usage of otherwise widely known and commonly used emotional words. This perspective therefore challenges current universal theories of emotions such as pleasure, arousal, dominance (PAD) (Russell \& Mehrabian, 1977), wheel of emotions (WE) (Plutchik, 1980), and the consumption emotion set (CES) (Richins, 1997). Moreover, this perspective is in line with existing research that challenges grouping emotions and calls for in-depth analysis of each type of emotion individually (e.g., Griskevicius, Shiota \& Nowlis, 2010). The present analysis also extends similar work addressing the fluidity of spectators' emotions in their experiences of cricket games (Yassim, 2011). Whilst emotion appears as an essential part of experience in several scholarly papers such as (Hirschman \& Holbrook, 1982; Pine and Gilmore, 1998; Schmitt, 1999), the individualistic fluid nature of emotion highlighted in the results of this study challenges current understanding of emotion and particularly the universal perspective on emotion and experience; thus, bringing new insights into defining the essence of experience.

In addition, the third group of constructs identified as part of the online shopping experience construction is risk and trust constructs. Unlike existing research that emphasizes the importance of risk perception as a key issue in online shopping (e.g. Kim \& Forsythe, 2009; Miyazaki \& Fernandez, 2001), the findings of this study show no evidence of risk as an important part of the construction of the online fashion 
shopping experience. This finding is vital to our understanding of how the nature of experience in the context of online fashion shopping is changing. For instance, Perry et al. (2013, p.2) argue that: "For fashion, intangibility is the principle determinant of risk in online purchase (Yu et al., 2012) rather than security, privacy and system security concerns (Eggert, 2006). The lack of sensory input prevents consumers from being able to make an informed purchase decision (Yu et al., 2012; Merle et al., 2012; Eggert, 2006)". However, despite the prior research focusing on risk reduction in online fashion shopping, it is arguably not a relevant construct for the online fashion shoppers themselves in terms of their individual experiences. It could be argued that prior experience, level of expertise and familiarity with this type of experience contribute to minimising risk, thus, marginalising its role in the experience construction. Arguably, risk reduction could be significantly different in non-online shoppers, in which case addressing risk issues remains valid to attract non-online shoppers to online shopping, but this lies beyond the scope of this paper.

Despite the marginal role of risk perception in the construction of experience, trust appears as an important factor. While trust may be regarded as the rational calculation of risk by some (e.g. Plutchik, 1980), it is important to acknowledge, in line with Nickel and Vaesen (2012), that perspectives on trust can depend on expectations or individual attitudes. Indeed, this perspective also became evident in this study (e.g. the idea of a loss of trust when a participant's expectations are not met by a company that delivers worldwide yet fails to deliver to a certain European country). Therefore, trust as defined in this study is not explained by risk perception but by other attitudinal and experiential dimensions.

The findings in relation to behavioural constructs are in line with established research in this area such as approach-avoidance theory. The approach-avoidance theory of 
behaviour (Eroglu, et al., 2001; Ezeh \& Harris, 2007) explains these constructs as being ones in which the participant anticipates either an approach behaviour (such as interacting, engaging, buying, or revisiting a website), or an avoidance behaviour (such as ignoring, leaving a website, or giving up on the task).

Finally, the situational constructs identified as part of the experience construction brings an important perspective to defining what an experience is and how it could possibly vary based on different situational contexts.

The literature discusses situations and situational constructs as structures for the expectation of activities in a plan of behaviour (Dewey, 1958); Kelly (1955) refers to these as context of the anticipation of events. Further, Belk defines the situation "as comprising all those factors particular to a time and place of observation which do not follow from a knowledge of personal (intra-individual) and stimulus (choice alternative) attributes and which have a demonstrable and systematic effect on current behaviour" (1975, p.158).

Indeed, this perspective suggests that understanding the situation requires its separation from physical surroundings and the personal traits of individual consumers and their behaviours. Bitner (1990) also reinforces this separation by suggesting that physical surroundings and employee responses, in addition to situational variables, are considered in predicting and explaining consumer behaviour. In keeping with this prior research, the findings of the present study emphasize the importance of situational variables and include them as core aspects of constructing online fashion shopping experiences, and of the contextual whole that defines them.

Accordingly, the findings of this study support specific aspects of the nature of experience such as it emotional, perceptual and behavioural dimensions. However, unlike previous research, this paper reaches a new understanding of the fluid nature of 
experience by adopting a holistic approach to studying experience as it is constructed by the individual user. While previous research has focused on studying parts of the experience e.g. experience of flow (Hoffman \& Novak, 1996; Chen, Wigand \& Nilan, 1999; Liu, Chu, Huang \& Chen, 2016; Skadberg and Kimmel; 2004) or the antecedents and consequences of experience (e.g. Bilgihan et al., 2016; Rose et al., 2012), such research rarely explored the essence of the experience itself in any great depth (Petermans, et at., 2013). Therefore, by presenting a construction of the essence of what an experience is and by approaching this topic from a holistic non-limiting approach, this research, as abovementioned, contributes a new perspective that is of theoretical and managerial implications (discussed below).

\section{Conclusion}

The findings of this research have extended the previously limited knowledge and understanding of the online shopping experience. First, by exploring the essence of the experience this paper moved beyond models of the antecedents and consequences of experience (e.g. Bilgihan, 2016; Rose et al., 2011) or environmental effect (Eroglu et al., 2001; Schmitt, 1999; Pine \& Gilmore, 1998). This study addressed the nature of experience by exploring how it is constructed by customers with regard to five categories of key constructs: perception of the environment, emotion, risk and trust, behaviour, and situation. In line with Petermans's (2013) argument that there is a need for a holistic approach to experience research, the PCT approach adopted in this paper conceptualised what an experience is via the psychological construction and anticipation of events a person makes prior to an intentional or unintentional visit to an apparel website. This construction of emotions, situations, and perceptions of trust and of the environment shapes a journey of interactions involving approach and 
avoidance. This individualistic path is defined by a situational context, usually involving a task.

Most importantly, the present study has asserted that customer experience and emotion are fluid in nature, so variations in what an experience means is an expected outcome. Consequently, the paper asserts an outlook of fluid experience in which mutual agreement on the meaning of experience is unlikely to be achieved, so an experience should always be viewed as a dynamic, individualistic phenomenon rather than a static entity of a mutually-agreed abstraction.

The online shopping environment should always be viewed in terms of the individualistic constructions of individual consumers, and in light of the shared aspects they have in common. Most importantly, it should allow flexibility and a degree of mass customization to tailor individualistic experiences in which the environment and the individual are inseparable but united in the making of a customer experience. Indeed, the ultimate role of this environment is to bring the online shopping experience closer to real-life experiences.

This paper has explored the concept of the online shopping experience: this is a highly individualistic concept, but also one deemed essential for online businesses. Online retailers, marketers, customer experience managers, and web designers need to find ways to focus on the individual level of experience rather than attempting to employ universal understandings of the shopping experience. Approaches such as site mass customisation and in-depth navigation analysis of customer journeys could be promising in this area. In addition, in the case of the fashion industry, practitioners should focus on designing websites that bring the online fashion-shopping experience closer to that of real life. This not only includes the deployment of advanced visual technologies, but also the addressing of layout and navigation issues. 
Because practitioners must take into account the absence of "helpful staff" on their websites, all measures should be taken to ensure easy navigation and web atmospherics that account for the different types of situational contexts of an online shopping experience.

Despite the important insights this study brings into the literature of customer experience, a number of limitations to the present studies must be considered. Because this study adopted a research design in which the participants were individuals who were experienced in online fashion shopping, its findings can only be regarded as relevant to this population, and cannot be extended to novice shoppers who are unfamiliar with online fashion shopping. Indeed, any choice of sampling strategy always comes with a set of limitations. This paper used purposive sampling to identify candidates with prior recurrent experience of online fashion shopping, a decision which might arguably influence the generalizability of the findings. For instance, issues of perceived risk in online fashion shopping may still be of high importance to individuals lacking experience of shopping online. Future research should further investigate levels of perceived risk in order to better understand how non-online fashion shoppers can be encouraged to engage in online shopping. This study is also limited to examining consumer experience within a retailer's website rather than other media, such as social media platforms that are not connected to a retailer website. Examples of these include blogs and YouTube vlogs led by "fashion haulers". Such media seem to be major resources for diverse customers. Incorporating the influence of fashion haulers and the effectiveness of their integration in online fashion websites would therefore appear to be an important area of future research. 
Finally, this research has adopted a holistic approach to studying the experience of online shopping. Therefore, its scope excludes the fine detail of every construct that constituted the experience. Instead, emphasis was placed on how experiences are constructed by those experiencing them, in an expected trade-off between depicting the big picture and examining its details. Indeed, it is believed that "pixilating" this big picture will further enhance our understanding of online fashion-shopping experiences. 


\section{References}

Akçayır, M., Dündar, H., \& Akçayır, G. (2016). What makes you a digital native? Is it enough to be born after 1980?. Computers in Human Behavior,60, 435-440.

Anteblian, B., Filser, M., \& Roederer, C. (2013). Consumption experience in retail environments: A literature review. Recherche et Applications En Marketing (English Edition), 28(3), 82-109.

Baker, J., Parasuraman, A., Grewal, D., \& Voss, G. B. (2002). The influence of multiple store environment cues on perceived merchandise value and patronage intentions. Journal of Marketing, 66(2), 120-141.

Bannister, D. (1970). Perspectives in personal construct theory. Academic Press.

Bannister, D., \& Fransella, F. (1986). Inquiring man: The psychology of personal constructs. Routledge.

Bannister, D., \& Mair, J. M. (1968). Evaluation of Personal Constructs. Academic Press.

Belk, R. (1975). Situational variables and consumer behavior. Journal of Consumer Research, 2(3), 157-164.

Bilgihan, A. (2016). Gen Y customer loyalty in online shopping: An integrated model of trust, user experience and branding. Computers in Human Behavior, 61, 103113.

Bilgihan, A., Kandampully, J., \& Zhang, T. (2016). Towards a unified customer experience in online shopping environments: Antecedents and outcomes. International Journal of Quality and Service Sciences, 8(1), 102-119.

Bitner, M. J. (1990). Evaluating service encounters: The effects of physical surroundings and employee responses. The Journal of Marketing, 54(2), 69-82.

Bridges, E., \& Florsheim, R. (2008). Hedonic and utilitarian shopping goals: The online experience. Journal of Business Research, 61(4), 309-314.

Carù, A., \& Cova, B. (2003). Revisiting Consumption Experience: A More Humble but Complete View of the Concept. Marketing Theory, 3(2), 267-286.

Chang, H. H., \& Chen, S. W. (2008). The impact of online store environment cues on purchase intention Trust and perceived risk as a mediator. Online Information Review, 32(6), 818-841.

Chaudhuri, A. (1997). Consumption emotion and perceived risk: A macro-analytic approach . Journal of Business Research, 39(2), 81-92.

Chen, H., Wigand, R. T., \& Nilan, M. S. (1999). Optimal experience of web activities. Computers in human behavior, 15(5), 585-608.

Creswell, J. W. (2009). Research design: Qualitative, quantitative, and mixed methods approaches. Sage Publications, Inc.

Csikszentmihalyi, M. (1990). Flow: The Psychology of Optimal Experience. New York: Harper Perennial.

Dailey, L. (2004). Navigational web atmospherics: explaining the influence of restrictive navigation cues. Journal of Business Research, 57, 795-803. 
Demangeot, C., \& Broderick, A. J. (2007). Conceptualising consumer behaviour in online shopping environments. International Journal of Retail \& Distribution Management, 35(11), 878-894.

Dennis, C., Brakus, J. J., Gupta, S., \& Alamanos, E. (2014). The effect of digital signage on shoppers' behavior: The role of the evoked experience. Journal of Business Research, 67(11), 2250-2257.

Dewey, J. (1958). Experience and Nature. New York: Dover Publications.

Easterby-Smith, M., Thorpe, R., \& Holman, D. (1996). Using repertory grids in management. Journal of European Industrial Training, 20(3), 3-30.

Eroglu, S. A., Machleit, K. A., \& Davis, L. M. (2001). Atmospheric qualities of online retailing: A conceptual model and implications. Journal of Business Research, 54(2), 177-184.

Ezeh, C., \& Harris, L. (2007). Servicescape research: a review and a research agenda. The Marketing Review, 7(1), 59-78.

Fransella, F., Bannister, D., \& Bell, R. (2004). A Manual for Repertory Grid Technique. John Wiley \& Sons.

Gentile, C., Spiller, N., \& Noci, G. (2007). How to sustain the customer experience: An overview of experience components that co-create value with the customer. European Management Journal, 25(5), 395-410.

Goulding, C. (1999). Consumer research, interpretive paradigms and methodological ambiguities. European Journal of Marketing, 33(9/10), 859-873.

Grewal, D., Levy, M., \& Kumar, V. (2009). Customer experience management in retailing: An organizing framework. Journal of Retailing, 85(1), 1-14.

Griskevicius, V., Shiota, M., \& Nowlis, S. (2010). The many shades of rose-colored glasses: An evolutionary approach to the influence of different positive emotions. Journal of Consumer Research, 37(2), 238-250.

Ha, S., \& Stoel, L. (2009). Consumer e-shopping acceptance: Antecedents in a technology acceptance model. Journal of Business Research, 62(5), 565-571.

Hirschman, E. C., \& Holbrook, M. B. (1982). Hedonic consumption: Emerging concepts, methods and propositions. Journal of Marketing, 46(3), 92-101.

Ho, L. A., \& Kuo, T. H. (2010). How can one amplify the effect of e-learning? An examination of high-tech employees' computer attitude and flow experience. Computers in Human Behavior, 26(1), 23-31.

Hoffman, D., \& Novak, T. (1996). Marketing in hypermedia computer-mediated environments: Conceptual foundations. The Journal of Marketing. 60(3), 50-68

Holbrook, M., \& Gardner, M. (1993). An approach to investigating the emotional determinants of consumption durations: Why do people consume what they consume for as long as they consume it? Journal of Consumer Psychology. 2(2), $123-142$.

Jankowicz, D. (2005). The easy guide to repertory grids. England: Wiley.

Kamaladevi, B. (2010). Customer experience management in retailing. Business Intelligence Journal, 3(1), 37-54.

Kawaf, F., \& Tagg, S. (2012). Online shopping environments in fashion shopping: An 
SOR based review. The Marketing Review, 12(2), 161-180.

Kelly, G. A. (1955). The psychology of personal constructs. New York: W. W. Norton.

Kim, H., \& Lennon, S. J. (2010). E-atmosphere, emotional, cognitive, and behavioral responses. Journal of Fashion Marketing and Management, 14(3), 412-428.

Kim, J., \& Forsythe, S. (2009). Adoption of sensory enabling technology for online apparel shopping. European Journal of Marketing, 43(9-10), 1101-1120.

King, W. R., \& He, J. (2006). A meta-analysis of the technology acceptance model. Information \& Management, 43(6), 740-755.

Klaus, P. (2013). The case of Amazon. com: towards a conceptual framework of online customer service experience (OCSE) using the emerging consensus technique (ECT). Journal of Services Marketing, 27(6), 443-457.

Koo, D. M., \& Ju, S. H. (2010). The interactional effects of atmospherics and perceptual curiosity on emotions and online shopping intention. Computers in Human Behavior. 26(3), 377-388.

Kotler, P. (1973). Atmospherics as a marketing tool. Journal of Retailing, 49(4), 4864.

Koufaris, M. (2003). Applying the technology acceptance model and flow theory to online consumer behavior. Information Systems Research, 13(2), 205-223.

Lee, S., \& Jeong, M. (2012). Effects of e-servicescape on consumers' flow experiences. Journal of Hospitality and Tourism Technology, 3(1), 47-59.

Lee, Y., Kozar, K. A., \& Larsen, K. R. (2003). The technology acceptance model: Past, present, and future. Communications of the Association for information systems, 12(1), 752-780.

Lemke, F., Clark, M., \& Wilson, H. (2011). Customer experience quality: An exploration in business and consumer contexts using repertory grid technique. Journal of the Academy of Marketing Science, 39(6), 846-869.

Liu, H., Chu, H., Huang, Q., \& Chen, X. (2016). Enhancing the flow experience of consumers in China through interpersonal interaction in social commerce. Computers in Human Behavior, 58, 306-314.

Marsden, D., \& Littler, D. (2000). Exploring consumer product construct systems with the repertory grid technique. Qualitative Market Research: An International Journal, 3(3), 127-144.

McLean, G., \& Wilson, A. (2016). Evolving the online customer experience... is there a role for online customer support?. Computers in Human Behavior, 60, 602-610.

Russell, J. A., \& Mehrabian, A. (1977). Evidence for a three-factor theory of emotions. Journal of Research in Personality, 11(3), 273-294.

Meyer, C., \& Schwager, A. (2007). Understanding customer experience. Harvard Business Review, 85(2), 116-126.

Miyazaki, A. D., \& Fernandez, A. (2001). Consumer perceptions of privacy and 
security risks for online shopping. Journal of Consumer Affairs, 35(1), 27-44.

Nickel, P., \& Vaesen, K. (2012). Risk and trust. In S. Roeser, R. Hillerbrand, P. Sandin, \& M. Peterson (Eds.), Handbook of Risk Theory (pp. 858-876). Springer Science \& BusinessMedia.

Novak, T. P., Hoffman, D. L., \& Yung, Y. F. (2000). Measuring the customer experience in online environments: A structural modeling approach. Marketing Science, 19(1), 22-42.

Pace, S. (2004). A grounded theory of the flow experiences of Web users. International Journal of Human-Computer Studies, 60(3), 327-363.

Pantano, E., \& Priporas, C. V. (2016). The effect of mobile retailing on consumers' purchasing experiences: A dynamic perspective. Computers in Human Behavior, 61, 548-555.

Parasuraman, A., Zeithaml, V., \& Berry, L. (1988). Servqual: A multiple-item scale for measuring consumer perceptions of service quality. Journal of Retailing, 64(1), 12-40.

Perry, P., Blazquez, M., \& Padilla, S. (2013). Translating the need for touch to online fashion shopping via digital technology. In Proceedings of The First International Conference on Digital Technologies for the Textile Industries. The University of Manchester: UK. 1-11.

Petermans, A., Janssens, W., \& Van Cleempoel, K. (2013). A holistic framework for conceptualizing customer experiences in retail environments. International Journal of Design, 7(2). 1-18.

Pine, B., \& Gilmore, J. (1998). Welcome to the experience economy. Harvard Business Review, 76, 97-105.

Plutchik, R. (1980). Emotion: A psychoevolutionary synthesis. Harper \& Row New York.

Prensky, M. (2001). Digital natives, digital immigrants part 1. On the horizon,9(5), 16.

Richardson, M., Baird, J. A., Ridgway, J., Ripley, M., Shorrocks-Taylor, D., \& Swan, M. (2002). Challenging minds? Students' perceptions of computer-based World Class Tests of problem solving. Computers in Human Behavior, 18(6), 633-649.

Richins, M. L. (1997). Measuring emotions in the consumption experience. Journal of Consumer Research, 24(2), 127-146.

Rose, S., Clark, M., Samouel, P., \& Hair, N. (2012). Online customer experience in eretailing: an empirical model of antecedents and outcomes. Journal of Retailing. $88(2), 308-322$.

Rose, S., Hair, N., \& Clark, M. (2011). Online customer experience: A review of the business to consumer online purchase context. International Journal of Management Reviews, 13, 24-39.

Saunders, M., Lewis, P., \& Thornhill, A. (2009). Research methods for business students. Pearson Education. 
Schmitt, B. (1999). Experiential marketing. Journal of Marketing Management, 15(1), 53-67.

Skadberg, Y. X., \& Kimmel, J. R. (2004). Visitors' flow experience while browsing a Web site: its measurement, contributing factors and consequences. Computers in human behavior, 20(3), 403-422.

Su, Y. S., Chiang, W. L., Lee, C. T. J., \& Chang, H. C. (2016). The effect of flow experience on player loyalty in mobile game application. Computers in Human Behavior, 63, 240-248.

Tagg, S., \& Wilson, F. (2011). Construing business owners: are men and women really different? International Journal of Gender and Entrepreneurship, 2(1).

Walker, B. M., Harper, J., Lloyd, C., \& Caputi, P. (2003). Methodologies for the exploration of computer and technology transference. Computers in human behavior, 19(5), 523-535.

Webster, J., Trevino, L. K., \& Ryan, L. (1993). The dimensionality and correlates of flow in human-computer interactions. Computers in human behavior, 9(4), 411426.

Weinman, J. (2015). The Cloud and the Economics of the User and Customer Experience. IEEE Cloud Computing, 2(6), 74-78.

Yassim, M. S. (2011). The role of emotions in game experience: linking emotions, game experience and return intentions (Doctoral dissertation, University of Greenwich).

Zikmund, W. G., \& Babin, B. J. (2007). Exploring Marketing Research. Cengage Learning. 
Appendices

Appendix 1

\begin{tabular}{|c|c|c|c|c|c|c|c|c|c|c|c|}
\hline \multirow{2}{*}{$\begin{array}{l}\text { Construct's } \\
\text { Emergent Pole }\end{array}$} & \multicolumn{10}{|c|}{ Grid Elements } & \multirow{2}{*}{$\begin{array}{l}\text { Construct's } \\
\text { Implicit Pole }\end{array}$} \\
\hline & 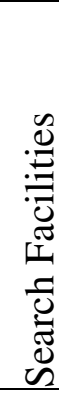 & 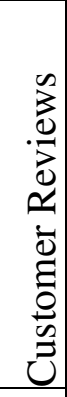 & 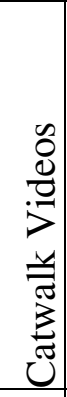 & 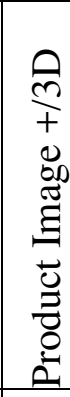 & 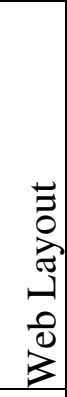 & 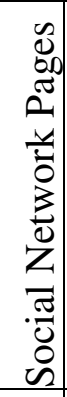 & $\begin{array}{l}0 \\
00 \\
00 \\
0 \\
0 \\
0 \\
0 \\
3 \\
0\end{array}$ & 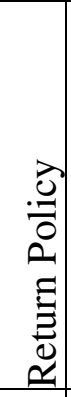 & 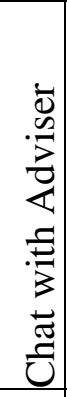 & 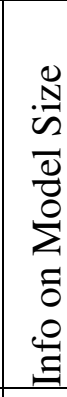 & \\
\hline $\begin{array}{l}\text { It brings a good } \\
\text { alternative to store } \\
\text { service }\end{array}$ & 5 & 3 & 2 & 4 & 4 & 3 & 1 & 1 & 2 & 5 & $\begin{array}{l}\text { The minimum } \\
\text { basics }\end{array}$ \\
\hline Glad and happy & 3 & 3 & 2 & 2 & 4 & 3 & 1 & 1 & 2 & 4 & Disappointed \\
\hline $\begin{array}{l}\text { Make me easily buy } \\
\text { more }\end{array}$ & 1 & 3 & 2 & 1 & 4 & 5 & 1 & 1 & 2 & 4 & $\begin{array}{l}\text { Only buy if the } \\
\text { product is really } \\
\text { good }\end{array}$ \\
\hline Low risk & 3 & 2 & 3 & 1 & 3 & 3 & 3 & 1 & 2 & 1 & High risk \\
\hline Vital, Essential & 1 & 5 & 3 & 1 & 1 & 5 & 1 & 1 & 5 & 1 & Useless \\
\hline At ease & 1 & 4 & 3 & 1 & 2 & 3 & 1 & 1 & 4 & 1 & Scared \\
\hline Comfortable & 1 & 5 & 3 & 1 & 2 & 5 & 1 & 1 & 5 & 1 & Unsettled \\
\hline
\end{tabular}


Appendix 2

Participants' profiles

\begin{tabular}{|c|c|c|c|c|}
\hline No. & Demographics & Browse for clothes & Shop for clothes & $\begin{array}{l}\text { Familiar } \\
\text { fashion } \\
\text { websites }\end{array}$ \\
\hline 3 & $\begin{array}{l}\text { Female (18-24) } \\
\text { year old }\end{array}$ & Very! Once a week! & $\begin{array}{l}\text { Very often!! I } \\
\text { love shopping } \\
\text { online }\end{array}$ & $\begin{array}{l}\text { Many!! } \\
\text { Rather all. }\end{array}$ \\
\hline 4 & $\begin{array}{l}\text { Female }(18-24) \\
\text { year old }\end{array}$ & Everyday & $\begin{array}{l}\text { Once/twice a } \\
\text { month }\end{array}$ & $5-6$ \\
\hline 5 & $\begin{array}{l}\text { Female }(18-24) \\
\text { year old }\end{array}$ & 2-3 times a week & $\begin{array}{l}\text { At least once a } \\
\text { week }\end{array}$ & 10 \\
\hline 6 & $\begin{array}{l}\text { Male }(>50) \text { year } \\
\text { old }\end{array}$ & 3-4 times a month & $6-8$ times a year & $3-4$ \\
\hline 7 & Male (18-24) & $\begin{array}{l}\text { Once a week } \\
\text { (sometimes even more) }\end{array}$ & $\begin{array}{l}\text { Once every } 1 \text { or } \\
2 \text { months }\end{array}$ & $10-12$ \\
\hline 8 & $\begin{array}{l}\text { Female }(18-24) \\
\text { year old }\end{array}$ & Almost everyday & $\begin{array}{l}5-10 \text { times a } \\
\text { year }\end{array}$ & 8 \\
\hline 9 & $\begin{array}{l}\text { Female }(18-24) \\
\text { year old }\end{array}$ & Around once a month & $\begin{array}{l}\text { It depends how } \\
\text { much money I } \\
\text { have }\end{array}$ & $4-5$ \\
\hline 10 & $\begin{array}{l}\text { Female }(18-24) \\
\text { year old }\end{array}$ & Once a week or more & $\begin{array}{l}3-4 \text { times a } \\
\text { month }\end{array}$ & 15 or more \\
\hline 11 & $\begin{array}{l}\text { Female }(25-35) \\
\text { year old }\end{array}$ & Everyday & Every week & $20+$ \\
\hline 12 & $\begin{array}{l}\text { Female }(25-35) \\
\text { year old }\end{array}$ & Regularly & Rarely & $6-7$ \\
\hline 13 & $\begin{array}{l}\text { Male (18-24) } \\
\text { year old }\end{array}$ & 2-3 times a week & Once a month & 6 \\
\hline 14 & $\begin{array}{l}\text { Female }(18-24) \\
\text { year old }\end{array}$ & 2-3 times a week & Once a month & 10 \\
\hline 15 & $\begin{array}{l}\text { Female }(18-24) \\
\text { year old }\end{array}$ & Everyday & Once a week & 20 \\
\hline
\end{tabular}




\begin{tabular}{|l|l|l|l|l|}
\hline 16 & $\begin{array}{l}\text { Female (18-24) } \\
\text { year old }\end{array}$ & Once/twice a week & Once a month & $5-10$ \\
\hline 17 & $\begin{array}{l}\text { Male (18-24) } \\
\text { year old }\end{array}$ & $1-2$ times a week & $\begin{array}{l}\text { 1-2 times every } \\
2-3 \text { months }\end{array}$ & 10 \\
\hline 18 & $\begin{array}{l}\text { Female (18-24) } \\
\text { year old }\end{array}$ & Once or twice per day & Once a week & 10 \\
\hline 19 & $\begin{array}{l}\text { Female (18-24) } \\
\text { year old }\end{array}$ & 3 times a week & Once a month & 7 \\
\hline 20 & $\begin{array}{l}\text { Female (36-50) } \\
\text { year old }\end{array}$ & Almost every week & Every month & $\begin{array}{l}\text { Too many } \\
\text { over 30) }\end{array}$ \\
\hline 21 & $\begin{array}{l}\text { Male (18-24) } \\
\text { year old }\end{array}$ & 3 Times a week & Once a month & 9 \\
\hline 22 & $\begin{array}{l}\text { Male (18-24) } \\
\text { year old }\end{array}$ & Weekly & $\begin{array}{l}\text { Every few } \\
\text { months }\end{array}$ & 15 \\
\hline 23 & $\begin{array}{l}\text { Female (18-24) } \\
\text { year old }\end{array}$ & $\begin{array}{l}\text { Once every 2-3 weeks } \\
\text { (less or more depending } \\
\text { on my needs })\end{array}$ & $\begin{array}{l}\text { Every 1-2 } \\
\text { months }\end{array}$ & $3-4$ \\
\hline 24 & $\begin{array}{l}\text { Female (18-24) } \\
\text { year old }\end{array}$ & $\begin{array}{l}\text { Faily } \\
\text { year old }\end{array}$ & $\begin{array}{l}\text { Once every }(\sim 3) \\
\text { months }\end{array}$ & 10 \\
\hline
\end{tabular}

